\title{
Influence of environmental conditions on radial patterns of sap flux density of a 70-year Fagus crenata trees in the Naeba Mountains, Japan
}

\author{
Mitsumasa Kubota $^{\text {a* }}$, John TENHUnEN ${ }^{\mathrm{b}}$, Reiner ZIMMERMANN ${ }^{\mathrm{c}}$, Markus SCHMIDT ${ }^{\mathrm{b}}$, \\ Yoshitaka KAKUBARI ${ }^{\mathrm{a}}$ \\ a Institute of Silviculture of Forest Resources, Faculty of Agriculture, University of Shizuoka, Ohya 836, Shizuoka 422-8529, Japan \\ ${ }^{b}$ Department of Plant Ecology, University of Bayreuth, 95440 Bayreuth, Germany \\ ${ }^{c}$ Max Planck Institute for Biogeochemistry, PO Box 100164, 07743 Jena, Germany
}

(Received 27 May 2004; accepted 18 October 2004)

\begin{abstract}
Sap flux density (SFD) was measured continuously during 1999 with the heat dissipation method in natural Fagus crenata Blume (Japanese beech) forests growing at $900 \mathrm{~m}$ on the northern slope of the Kagura Peak of the Naeba Mountains near the Sea of Japan. Radial variations in xylem daily SFD ( $\mathrm{SFD}_{\text {day }}$ ) on three trees were investigated during the growing season. The radial pattern of $\mathrm{SFD}_{\text {day }}$ that reached a maximum just behind of the cambium layer and then decreased exponentially was described by applying the Weibull function based on sensor measurements at $20 \mathrm{~mm}$ intervals. SFD day ratio of $20-40 \mathrm{~mm}$ depth (the value of $0-20 \mathrm{~mm}$ depth was $100 \%$ ) increased by $10-32 \%$ because of soil drying. The peak value of the Weibull function shifted to $2-10 \%$ interior by those changes in the relative xylem depth. The variation of the radial pattern of $\mathrm{SFD}_{\text {day }}$ under different environmental conditions was expressible as the shift of the peak position of the Weibull function.
\end{abstract}

diffuse-porous / Granier sensor / soil moisture / drought / Weibull function

Résumé - Influences des conditions environnementales sur les patrons radiaux de densités de flux de sève de Fagus crenata âgés de 70 ans dans les montagnes de Naeba au Japon. La densité de flux de sève (SFD) a été mesurée en continu pendant l'année 1999 avec la méthode de dissipation de chaleur dans une forêt naturelle de Fagus crenata Blume (hêtre du Japon) située à $900 \mathrm{~m}$ d'altitude sur un versant nord prés de la mer du Japon. Les variations radiales journalières de SFD ( SFD $_{\text {jour }}$ ) de trois arbres ont été étudiées pendant la saison de croissance. Le patron radial de $\mathrm{SFD}_{\text {jour }}$ atteint un maximum juste derrière la couche du cambium et puis décroît de façon exponentielle et est décrit par la fonction Weibull sur la base des mesures des capteurs à des intervalles de temps de $20 \mathrm{~mm}$. Le rapport de 20 à $40 \mathrm{~mm}$ (la valeur de 0 à 20 mm était égale à $100 \%$ ) s'est accru de 10 à $32 \%$ à cause du dessèchement du sol. Le pic de la valeur de la fonction Weibull passe de 2 à $10 \%$ par ces changements de valeur relative de l'épaisseur du xylème. La variation du patron radial de SFD $_{\text {jour }}$ Sous différentes conditions environnementales était exprimable par le déplacement de la position du pic de la fonction Weibull.

poreux diffus / capteurs de Granier / humidité du sol / sécheresse / fonction Weibull

\section{INTRODUCTION}

Estimation of water balance in mountain catchments of Japan depends critically on the methods used to quantify water use by forest stands on the slopes. Forest stand evapotranspiration is impossible to measure directly, for example to measure via eddy covariance, due to complex mountain topography in which trees grow up to several tens of meters. Sap flux measurements by heat dispersion $[4,5]$, on the other hand, allow estimation of the transpiration component of ET in non-homogeneous terrain $[8,21]$. To obtain estimates of total water use by individual trees, it is necessary to integrate sap flux density across the sapwood area when sapwood radial width is greater than the usual $2 \mathrm{~cm}$ length of the Granier sensor $[17,26]$. In conifer and ring-porous trees, sapwood depth can be determined from fresh cores exhibiting differences in color in response to dye application [2] or in density due to differences in water content (sapwood versus heartwood; Köstner et al. [17]). In addition, computer tomography [11] and thermal IR-imaging [6] have been used to quantify sapwood area. Furthermore, the sharp boundary between sapwood and heartwood can be observed via associated decreases in sap flux density by inserting the Granier sensor to different radial depths [8, 16, 23].

In contrast, the boundary between the sapwood and heartwood is indistinct and cannot be visually determined for the diffuseporous beech trees investigated in this study. It is necessary to measure sap flux density as a function of depth in the xylem in order to estimate tree total water use. Granier et al. [9, 10], Köstner et al. [17] and Schafer et al. [30] reported that sap flux

* Corresponding author: kubota@earth.ocn.ne.jp 
density decreases exponentially from the outer to the inner sapwood in Fagus sylvatica. Especially clear, exponentially decreasing functions were measured in the small diameter trees by Schafer et al. [30] with the average measurement tree diameter $=26 \mathrm{~cm}$, and by Granier et al. [9] with the diameter of the measurement trees $=10$ to $21 \mathrm{~cm}$. Nadezhdina et al. [20] and Ford et al. [3] recently reported that the sap flux density reaches a maximum value in the interior of the cambium layer and was shown to decrease exponentially along the radial axis of the xylem. We assumed a regular transition in the sap flux density along the radial axis in the xylem by fitting the Weibull function to three measurements (0-20- and 20-40- and 40-60-mm xylem depth) with 20-mm long sensors.

We assumed that radial patterns in sap flux density may be more complex, particularly exhibiting a time dependence as habitat conditions change on the measurement period. Thus, shifts in the Weibull function fit to the data may occur. To clarify the radial patterns in sap flux density along radial sections of the xylem, we have examined how variations in radiation input (PPFD), vapour pressure deficit (VPD) and soil moisture are related to changes in sap flux density measured at different depths in the trees. The study was conducted on trees growing at $900 \mathrm{~m}$ in a natural Fagus crenata forested mountain region of Japan.

\section{MATERIALS AND METHODS}

\subsection{Site description}

The study area is located in the Naeba Mountains ca. $50 \mathrm{~km}$ northeast of Nagano. The sites were established in 1970 for long-term ecological monitoring along an altitudinal gradient within the framework of IBP [13]. On the northern slope of Kagura Peak, natural Japanese beech forests (Fagus crenata Blume) grow at elevations of $550 \mathrm{~m}$ to $1600 \mathrm{~m}$.

The study site $\left(36^{\circ} 53^{\prime} \mathrm{N}\right.$ and $\left.138^{\circ} 46^{\prime} \mathrm{E}\right)$ is located on a northeast facing mountain slope at an elevation of $900 \mathrm{~m}$. Stand biomass distribution, leaf area index and other structural parameters, as well as growth have been documented through continued observations over a period of more than 30 years [14]. Stand density is ca.1200 stems per ha, the mean stand canopy height is $19.1 \mathrm{~m}$, the mean diameter at breast height (DBH) is $20.9 \mathrm{~cm}$, and the age of trees is 70-year. LAI of the canopy is 5.2, and radiation penetrating the canopy is quite low. The basal area (more than DBH $4.5 \mathrm{~cm}$ ) is $49.1 \mathrm{~m}^{2} \mathrm{ha}^{-1}$. The dominant tree of this site (plot size $600 \mathrm{~m}^{2}$ ) is Fagus crenata the relative basal area (DBH: more than $4.5 \mathrm{~cm}$ ) occupied by the Fagus crenata is $92.3 \%$. The upper canopies of the forest stands are dominated by Fagus crenata, with occasional occurrence of Quercus mongolica var. grosseserrata, Magnolia obovata and Acanthopanax. A diverse understory of shrubs occurs with Viburnum furcatum, Lindera umbellata, Acer rufinerve, Clethra barbinervis, Acanthopanax sciadophylloides, Daphniphyllum humile and Sasa kurilensis.

The bedrock in the study area is predominantly andesite and basalt, on which moderately moist brown forest soil has formed. Climatically, this region along the Japan Sea coast is characterized by a high precipitation of ca. $2100 \mathrm{~mm}_{\text {year }}{ }^{-1}$, with large quantities of precipitation falling as snow in winter, leading to snow cover of three to four meters. A strong seasonal pattern in summer precipitation, however, often reduces water availability during August. The amount of precipitation during the growing season was $1070 \mathrm{~mm}$ at study sites in 1999. Mean annual air temperature was $9.3{ }^{\circ} \mathrm{C}$ at study sites in 1999 . Snow remained until the beginning of May, and beech leaves begin to flush in late April or early May, while autumn leaf coloring starts in late October.

\subsection{Micrometeorology and soil moisture content}

Meteorological conditions were monitored from scaffolding towers that extended above the forest canopy. Soil variables were monitored in the immediate tower vicinity, while precipitation was measured in large clearings at the forest edge with tipping bucket rain gauges (RG1, Delta-T Devices, England). PPFD was measured with LI-190 sensors (LI-COR, USA), and solar irradiance with LI-200 pyranometers (LICOR, USA) above the canopy on the towers. Wind speed was measured with cup anemometers similarly installed above the canopy (AN1, Delta-T Devices, England). Soil volumetric water content was measured via time-domain reflectometry (ML2 Theta Probe, Delta-T Devices, England) at a depth of $0.25 \mathrm{~m}$. TDR sensors were calibrated by gravimetric determinations of water content in multiple cores of $100 \mathrm{~cm}^{3}$ that were extracted in the neighborhood of the sensors. Light sensors were scanned at 10-s intervals; the other sensors at 30-s intervals. All variables were averaged over $30 \mathrm{~min}$ and logged (DL2e with LAC1, Delta-T Devices, England). Additionally, air temperature and relative humidity were measured with thermistor and capacitor sensors installed at the heights of $15 \mathrm{~m}$ within the tree crowns. The observations were logged at 30-min intervals (RS-11, TABAI-ESPEC, Japan) and subsequently used to calculate vapor pressure deficit [33].

\subsection{Sap flux density (SFD) measurements}

Xylem sap flux density (SFD) was monitored continuously throughout the growing season using the heat dissipation method according to Granier $[4,5]$. Heating of the upper probe was carried out along a $20 \mathrm{~mm}$ long winding in all cases. The paired needles, however, were of different lengths in order to allow observation of SFD at different depths: 0 to $20 \mathrm{~mm}, 20$ to $40 \mathrm{~mm}$ and 40 to $60 \mathrm{~mm}$ from the cambium. The heated probes were positioned on the trunk circumferentially as close to one another as possible.

The sensors were installed between the end of April before the leaves flushed. The sensors were removed in November after leaves had fallen to avoid damage by heavy winter snow. Healthy individual beech trees contributing to the main layer of the canopy were selected as summarized in Table I. The situation of the three measurement trees within the stand is illustrated in Figure 1. The DBH of measurement trees were $26 \mathrm{~cm}$ to $35 \mathrm{~cm}$, while the range in stem diameter at breastheight in the stand was $19 \mathrm{~cm}$ to $41 \mathrm{~cm}$.

All sensor installations were made on the north-facing side of the trees and covered with a radiation shield to reduce thermal load on the sensors. Power was provided by lead-acid batteries that were recharged with solar panels (SP75, SIEMENS, USA) via a charge controller (ProStar-30, Morningstar-Co, USA). The output value was monitored every $30 \mathrm{~s}$, and a 30-min mean value was logged (DL2e with LAC1 in double ended mode, Delta-T Devices, England) for each sensor.

\subsection{Aggregation to daily values}

This study utilized data of sap flux density and environmental factors measured from April 20 to November 15, 1999 (cf. Fig. 2). The duration of the growing period was from May 6 to October 29 during this year. The growth period was divided into four periods: (i) the leaf expansion stage (from 20 April to May 31), (ii) the first half of the mature stage (June and July), (iii) the latter half of the mature stage (August and September), and (iv) the leaf senescence period (from first October to November 10).

Since the main interest is in seasonal and long-term trends, driving variables and the tree physiological property SFD were aggregated to daily values. This is particularly useful, since the measured short-term values of SFD exhibit time lags diurnally in response to environmental variables [7, 15, 23, 29, 31, 34], while aggregated data demonstrate the dependencies of overall water use with respect to environmental trends (see also Phillips and Oren [27]). Furthermore, meteorological 


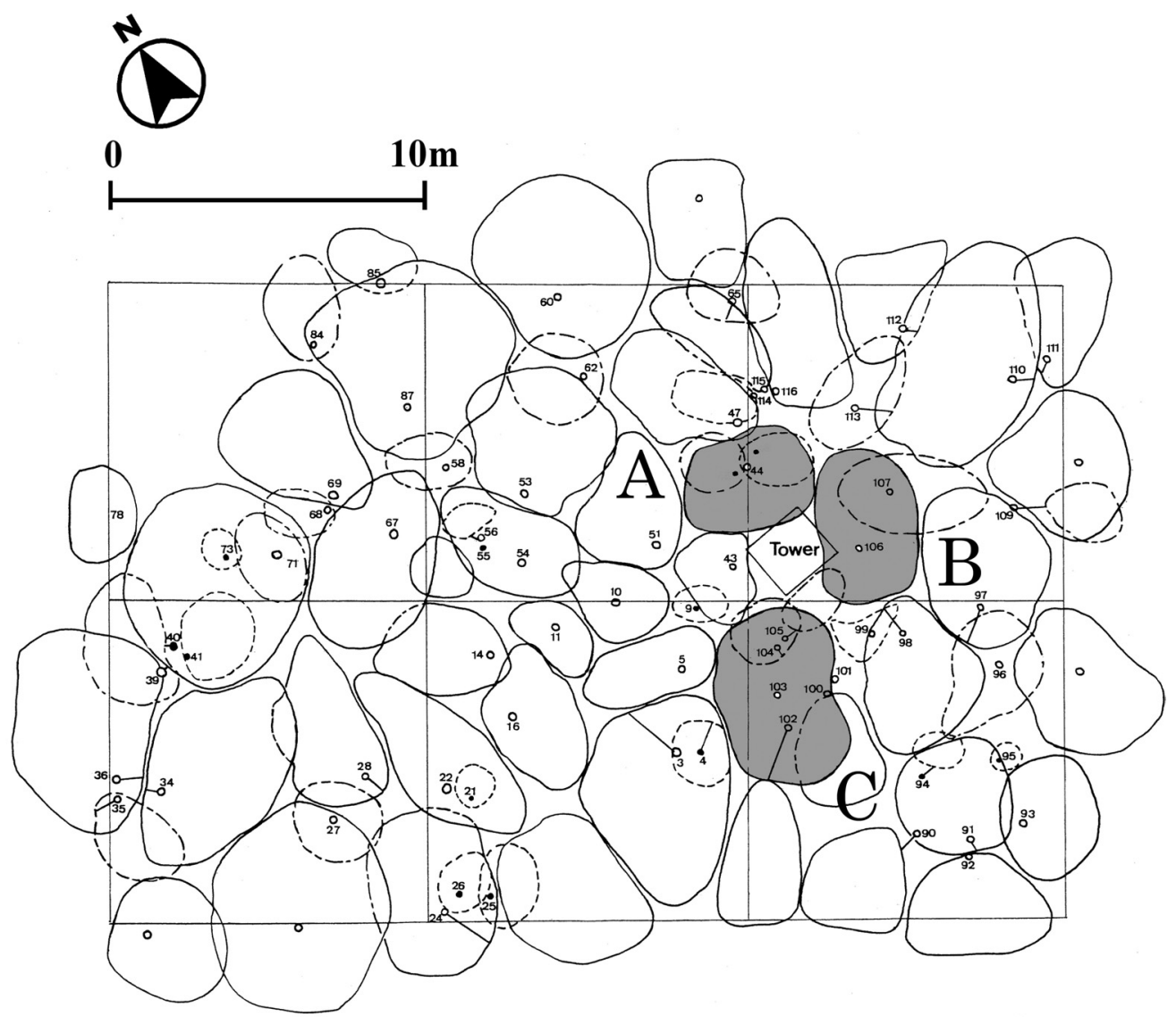

Figure 1. Map of projected canopy areas of the investigated Fagus crenata trees in the Naeba Mountains, Japan. The shaded canopies indicate the measurement trees.

Table I. General characteristics of the investigated Fagus crenata trees at 900-m elevation in the Naeba Mountains, Japan.

\begin{tabular}{lccccc}
\hline Tree No. & $\begin{array}{c}\text { Tree diameter at breast } \\
\text { height }(\mathrm{cm})\end{array}$ & $\begin{array}{c}\text { Tree height } \\
(\mathrm{m})\end{array}$ & $\begin{array}{c}\text { Tree diameter at } \\
\text { measurement }(\mathrm{cm})\end{array}$ & $\begin{array}{c}\text { Height of sensor } \\
(\mathrm{m})\end{array}$ & $\begin{array}{c}\text { Canopy project area } \\
\left(\mathrm{m}^{2}\right)\end{array}$ \\
\hline A & 25.6 & 21.7 & 22.7 & 3.5 & 11.2 \\
B & 31.7 & 19.8 & 29.0 & 3.5 & 13.4 \\
C & 35.1 & 19.6 & 31.5 & 3.5 & 18.5 \\
\hline
\end{tabular}

data is often available on a daily basis at many sites [35]. Thus, the temporal upscaling of our results permits comparisons and use of the data in a broader context for study of Japanese forests.

PPFD and precipitation measurements were converted to daily (24-h) sums $\left(\mathrm{PPFD}_{\text {day }}\right.$ and $\left.\mathrm{P}_{\text {day }}\right)$, and vapor pressure deficit was converted to the daytime mean $\left(\mathrm{VPD}_{\text {day }}\right)$. Soil moisture was expressed as a daily (24-h) mean of the volumetric water content $\left(\theta_{\text {day }}\right)$. SFD measured with each sensor was integrated over the day $\left(\mathrm{SFD}_{\text {day }}\right)$, providing a water flux density at daily (24-h) scale appropriate for the particular sensor location.

\subsection{Estimate of radial patterns of $\mathrm{SFD}_{\text {day }}$ using Weibull function in the xylem}

Results for clear days with high water availability $\left(\mathrm{PPFD}_{\text {day }}=35\right.$ $45 \mathrm{~mol} \mathrm{~m}^{-2} \mathrm{day}^{-1}, \theta_{\text {day }}>50 \%$ ) are illustrated in Figure 3 . We used relative depth for the radial depth in the xylem [18] expressed as 0 at the cambium and $100 \%$ at the center of the trunk. White bars indicate actual measured values of $\mathrm{SFD}_{\text {day. }}$. The width of each bar represents the span of an individual sensor. The $\mathrm{SFD}_{\mathrm{day}}$ is calculated as a mean radial value of the xylem over a depth of $20 \mathrm{~mm}$ because that is the length of the Granier sensors employed.

We assumed a regular transition in the radial value of the $\mathrm{SFD}_{\text {day }}$ according to the Weibull function fit to three data points (0-20 and 20-40- and 40-60-mm xylem depth) measured with 20-mm sensors. The Weibull function takes the following form:

$y=a\left(\frac{c-1}{c}\right)^{\frac{1-c}{c}}\left[\frac{x-d}{b}+\left(\frac{c-1}{c}\right)^{\frac{1}{c}}\right]^{c-1} e^{-\left[\frac{x-d}{b}+\left(\frac{c-1}{c}\right)^{\frac{1}{c}}\right]^{c}}+\frac{c-1}{c}$

where " $y$ " indicates $\mathrm{SFD}_{\text {day }}$, the coefficient " $a$ " determines the peak value of $\mathrm{SFD}_{\mathrm{day}}$, the coefficients " $b$ " and " $c$ " determine curvature, the 


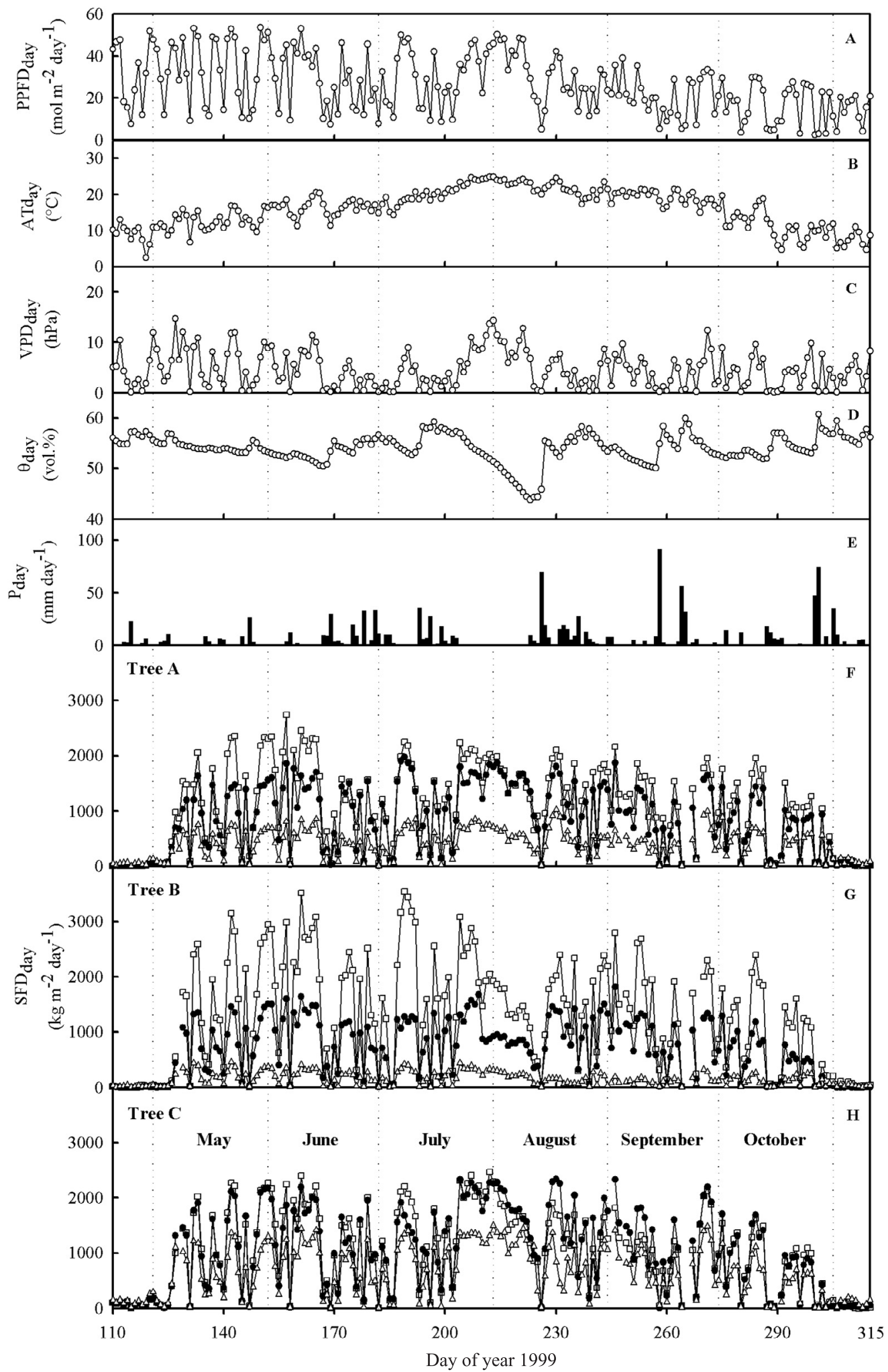

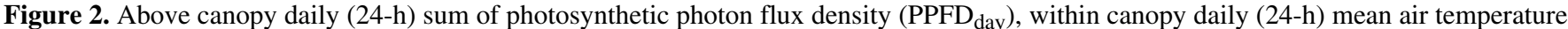
$\left(\mathrm{AT}_{\text {day }}\right)$ and daytime mean vapor pressure deficit $\left(\mathrm{VPD}_{\text {day }}\right)$, daily $(24-\mathrm{h})$ mean soil volumetric water content at a $0.25 \mathrm{~m}$ depth $\left(\theta_{\text {day }}\right)$, daily (24-h) sum of precipitation $\left(\mathrm{P}_{\text {day }}\right)$, and daily (24-h) sum of sap flux density $\left(\mathrm{SFD}_{\text {day }}\right)$ in 1999 (from April 20 to November 10) at 900 -m site in the Naeba Mountains, Japan. SFD day was measured at three depths; 0-20mm (open square $\square$ ), 20-40mm (closed circle $\bullet$ ) and 40-60 mm (open triangle $\triangle$ ). 


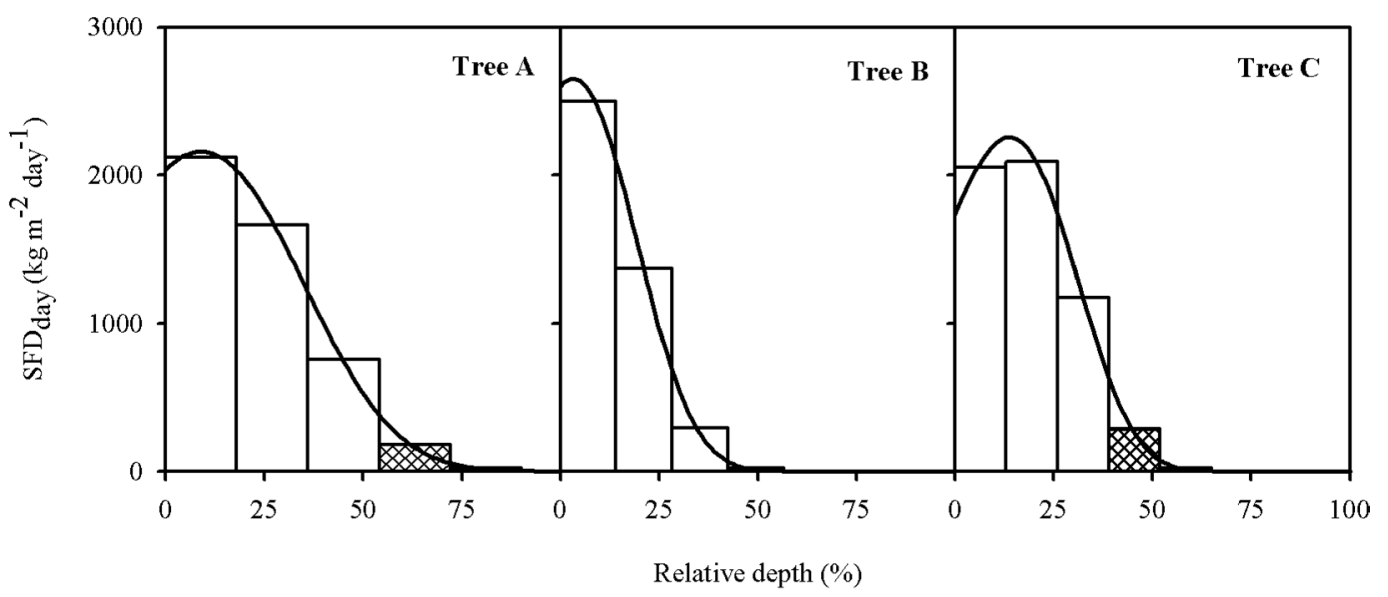

Figure 3. Radial patterns of $\mathrm{SFD}_{\text {day }}$ using Weibull function in the xylem. The radial depth is expressed as 0 at the cambium and $100 \%$ at the center of the trunk. Width of each bar depends on the sensor length. The white bars graph shows measured values $\mathrm{SFD}_{\text {day }}$ shown is a mean value during fine weather conditions $\left(\mathrm{PPFD}_{\mathrm{day}}=35-45 \mathrm{~mol} \mathrm{~m}^{-2}\right.$ day $\left.^{-1}\right)$ and with abundant soil moisture. Dark bars are estimated values approximated by the Weibull function (solid curve in the figure).

coefficient " $d$ " is a depth that the curve becomes the peak, and " $x$ " represents the radial depth in the xylem.

The area below the fitted Weibull function is equal to the summed area of the bars for each depth (0-20 mm, 20-40 mm and 40-60 mm). According to this analysis, the $\mathrm{SFD}_{\text {day }}$ reaches a maximum just behind of the cambium layer and then decreases exponentially as suggested by Nadezhdina et al. [20] and Ford et al. [3]. Furthermore, the Weibull function enables estimation of $\mathrm{SFD}_{\text {day }}$ deeper than deepest sensor insertion $(60 \mathrm{~mm})$.

\section{RESULTS AND DISCUSSION}

\subsection{Forest microclimate and variations in soil moisture content}

Daily rainfall $\left(\mathrm{P}_{\mathrm{day}}\right)$ in late summer was extremely low with no measured rainfall between July 25 and August 12 as shown in Figure 2E. In contrast, rainfall during the remaining period of study was more evenly distributed. The seasonal trend in $\theta_{\text {day }}$ at $0.25 \mathrm{~m}$ depth can be explained by the differences in rainfall input and potential water extraction by transpiration. Due to the prolonged dry period, $\theta_{\text {day }}$ exhibited a decline until August 11 but a recovery period was seen after the rainfall of August 12 (Fig. 2D). In contrast, $\theta_{\text {day }}$ showed little variation during the remaining period of study. The $P P F D_{\text {day }}$ and $V P D_{\text {day }}$ peaked on the summer solstice, and decreased gradually thereafter with transition to winter (Figs. 2A and 2C).

The relation between $P P F D_{\text {day }}$ and $\theta_{\text {day }}$ and the relation between PPFD $_{\text {day }}$ and $V P D_{\text {day }}$ were examined for each period (the leaf expansion stage, the first half of the mature stage, the latter half of the mature stage, and the leaf senescence period). The $\theta_{\text {day }}$ was independent of changes in PPFD day, although low values occurred in $\theta_{\text {day }}$ during the third period. VPD day was dependent on PPFD $_{\text {day }}$ but the relationship changed according to the period of year examined. Variations in $\mathrm{VPD}_{\text {day }}$ were high during the first half of the mature stage, although a clear dependence on PPFD $_{\text {day }}$ may be recognized. We considered that the variation in $\mathrm{VPD}_{\text {day }}$ occurred due to the inflow of drier or wetter air (including rainfall events) with changing weather systems as well as the influence of these on evapotranspiration.

\subsection{Radial patterns of $\mathrm{SFD}_{\mathrm{day}}$ with different environmental condition}

Figures $2 \mathrm{~F}-2 \mathrm{H}$ express the seasonal change of $\mathrm{SFD}_{\text {day }}$ in each depth in each tree. The strongest influences on $\mathrm{SFD}_{\text {day }}$ are first PPFD $_{\text {day }}$ and in correlation with this $\mathrm{VPD}_{\text {day. The influence of }}$ $\theta_{\text {day }}$ is recognizable in the slow decrease in maximum $\mathrm{SFD}_{\text {day }}$ between July 30 and August 15 .

We continued analysis of variation in SFD $_{\text {day }}$ with trunk depth in each tree by selecting very different environmental conditions during the mature stage (the second and the third period). Three typical environmental conditions were selected: (i) Fine $\&$ Wet $\left(\mathrm{PPFD}_{\text {day }}\right.$ was $35-45 \mathrm{~mol} \mathrm{~m}^{-2} \mathrm{day}^{-1}$ and the $\theta_{\text {day }}$ was above $50 \%$ ), (ii) Cloud \& Wet $\left(\right.$ PPFD day $_{\text {das }} 15-$ $25 \mathrm{~mol} \mathrm{~m}^{-2}$ day $^{-1}$ and the $\theta_{\text {day }}$ was above $50 \%$ ), and, (iii) Fine $\&$ Dry $\left(\right.$ PPFD $_{\text {day }}$ was $35-45 \mathrm{~mol} \mathrm{~m}^{-2}$ day $^{-1}$ and the $\theta_{\text {day }}$ was below 50\%). The SFD day rate of 20-40 and 40-60 mm depth was expressed based on the value of 0-20 $\mathrm{mm}$ depth as shown in Figure 4. Henceforth, this percentage is referred to as the $\mathrm{SFD}_{\text {day }}$ ratio, if the depth profile of the $\mathrm{SFD}_{\text {day }}$ ratio is constant over a long period of time, measurement of SFD day at 0-20 mm can be extrapolated to the whole profile, as proposed by $\mathrm{Lu}$ et al. [19]. This is important, because measurements of SFD at greater depths in the trunk are difficult, expensive and timeconsuming.

Values of SFD $_{\text {day }}$ decreased gradually from 0-20 mm toward the center of the trunk in tree A and B in the suitable environmental condition (Fine \& Wet), as reported by Köstner et al. [17] for Fagus sylvatica. However, values of $\mathrm{SFD}_{\text {day }}$ increased from $0-20 \mathrm{~mm}$ to $20-40 \mathrm{~mm}$ and then decreased toward the center of the trunk in Tree $C$. This is a possible explanation for the results reported by Phillips et al. [26] and Lu et al. [19].

During a prolonged period without rain, sap flux decreased as the soil dried as has been observed by other authors [22, 24, $25,28,31,32,36]$. The relative change in response of $\mathrm{SFD}_{\text {day }}$ under drought conditions was essentially similar in all trees as shown in Table II. However, the $\mathrm{SFD}_{\text {day }}$ ratio of $20-40 \mathrm{~mm}$ depth increased respectively $32 \%, 12 \%$ and $10 \%$ in Tree A, 
Table II. Mean of $\mathrm{SFD}_{\text {day }}$ for each sensor insertion depth on typical environmental condition. $\mathrm{SFD}_{\text {day }}$ ratio $(\%)\left(\mathrm{SFD}_{\text {day }}\right.$ at $0-20 \mathrm{~mm}$ depth $=$ $100 \%)$. Coefficients of Weibull function with different environmental condition.

\begin{tabular}{|c|c|c|c|c|c|c|c|c|c|c|c|c|c|}
\hline & & \multicolumn{6}{|c|}{ Means of SFDday on typical condition } & \multicolumn{2}{|c|}{$\begin{array}{c}\text { SFDday ratio (\%) } \\
(0-20 \mathrm{~mm}=100 \%)\end{array}$} & \multicolumn{4}{|c|}{ Coefficients of Weibull function } \\
\hline & & \multicolumn{2}{|c|}{$0-20 \mathrm{~mm}$} & \multicolumn{2}{|c|}{$20-40 \mathrm{~mm}$} & \multicolumn{2}{|c|}{$40-60 \mathrm{~mm}$} & $20-40 \mathrm{~mm}$ & $40-60 \mathrm{~mm}$ & $a$ & $b$ & $c$ & $d$ \\
\hline & & & S.D. & & S.D. & & S.D. & & & & & & \\
\hline \multirow[t]{3}{*}{ Tree A } & Fin \& Wet & 2119 & 143 & 1661 & 157 & 757 & 121 & 78.4 & 35.7 & 2161 & 90.2 & 3.7 & 9.0 \\
\hline & Cloud \& Wet & 1336 & 278 & 1080 & 204 & 455 & 116 & 80.8 & 34.1 & 1380 & 68.0 & 3.2 & 11.8 \\
\hline & Fine \& Dry & 1461 & 34 & 1513 & 25 & 512 & 42 & 103.6 & 35.0 & 1761 & 61.2 & 3.8 & 19.0 \\
\hline \multirow[t]{3}{*}{ Tree B } & Fin \& Wet & 2501 & 440 & 1368 & 280 & 293 & 84 & 54.7 & 11.7 & 2653 & 58.0 & 3.8 & 3.2 \\
\hline & Cloud \& Wet & 1704 & 405 & 1028 & 240 & 134 & 68 & 60.3 & 7.9 & 1786 & 69.4 & 5.5 & 8.3 \\
\hline & Fine \& Dry & 1283 & 34 & 791 & 17 & 208 & 4 & 61.7 & 16.2 & 1377 & 21.2 & 1.8 & 7.5 \\
\hline \multirow[t]{3}{*}{ Tree C } & Fin \& Wet & 2057 & 260 & 2091 & 216 & 1174 & 278 & 101.7 & 57.1 & 2257 & 94.2 & 5.6 & 13.8 \\
\hline & Cloud \& Wet & 1217 & 263 & 1402 & 323 & 807 & 247 & 115.2 & 66.3 & 1472 & 76.0 & 5.1 & 16.4 \\
\hline & Fine \& Dry & 1519 & 42 & 1697 & 116 & 1169 & 48 & 111.7 & 76.9 & 1764 & 50.0 & 2.9 & 15.9 \\
\hline
\end{tabular}

$\mathrm{B}$ and $\mathrm{C}$ though changed the environmental condition (differences between Fine \& Wet and Fine \& Dry conditions) as shown in Table II. This pattern is consistent with patterns found in other diffuse-porous species [19]. In contrast, Phillips et al. [26] found that as soil dried, the SFD ratio $(20-40 \mathrm{~mm} / 0-20 \mathrm{~mm}$ ) decreased about $20 \%$ in Pinus taeda L. from $44 \%$ to $36 \%$. Thus, although for a given tree a particular depth profile may remain constant over a period of time, there is no universal profile for all trees.

\subsection{Potential generalization of radial patterns using the Weibull function}

As shown in bar charts of Figure 3, the relative sap flux density in a sequence of measurements with increasing depth in the trunk are dependent on the exact location of each sensor and individual tree characteristics, i.e., the pattern is different with every tree. Assuming a general pattern according to the Weibull function, the observations for all three trees are similarly described. The Weibull function of response is compatible with the reports of Nadezhdina et al. [20], Ford et al. [3] and Hunt and Beadle [12] who measured the radial variation in flow within the xylem in detail in several different tree species. Altogether, the peak of the Weibull function and the peak of $S_{F} D_{\text {day }}$ at intervals of $20 \mathrm{~mm}$ occurred in a different xylem depth. Based on assumption that sap flow varies with depth according to the Weibull function, the apparent conflicting results obtained with diffuse-porous trees by Köstner [17] and Phillips et al. [26] that propose different types of response with depth in the trunk are resolved. Considering that the theoretical response with depth described by the Weibull function permits a changing position of the peak value in flow, the relationship in flow between two sensors in the outer xylem may either show a large difference or none at all.

Use of three sensors as in this study, demonstrates clearly the decrease in flow in the inner xylem of beech and provides adequate information for fitting of the Weibull response curve.

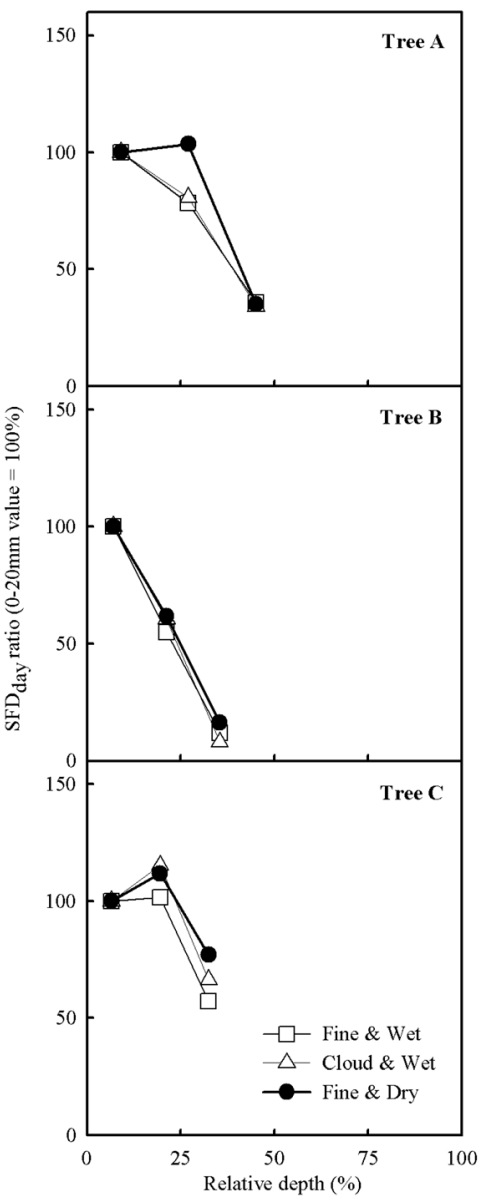

Figure 4. Depth profiles of $\mathrm{SFD}_{\text {day }}$ ratio $(\%)\left(\mathrm{SFD}_{\text {day }}\right.$ at $0-20 \mathrm{~mm}$ depth $=100 \%$ ) under three different sets of environmental conditions (using data from June to September); (i) fine weather $\left(\mathrm{PPFD}_{\text {day }}=35\right.$ $45 \mathrm{~mol} \mathrm{~m}^{-2}$ day $^{-1}$ ) and abundant $\theta_{\text {day }}$ (soil moisture content above $50 \%$ ), (ii) cloudiness ( $\mathrm{PPFD}_{\mathrm{day}}=15-25 \mathrm{~mol} \mathrm{~m}^{-2} \mathrm{day}^{-1}$ ) and abundant $\theta_{\mathrm{day}}$, and (iii) fine weather $\left(\mathrm{PPFD}_{\mathrm{day}}=35-45 \mathrm{~mol} \mathrm{~m}^{-2} \mathrm{day}^{-1}\right)$ and low $\theta_{\text {day }}$ (soil moisture content below $50 \%$ ). 

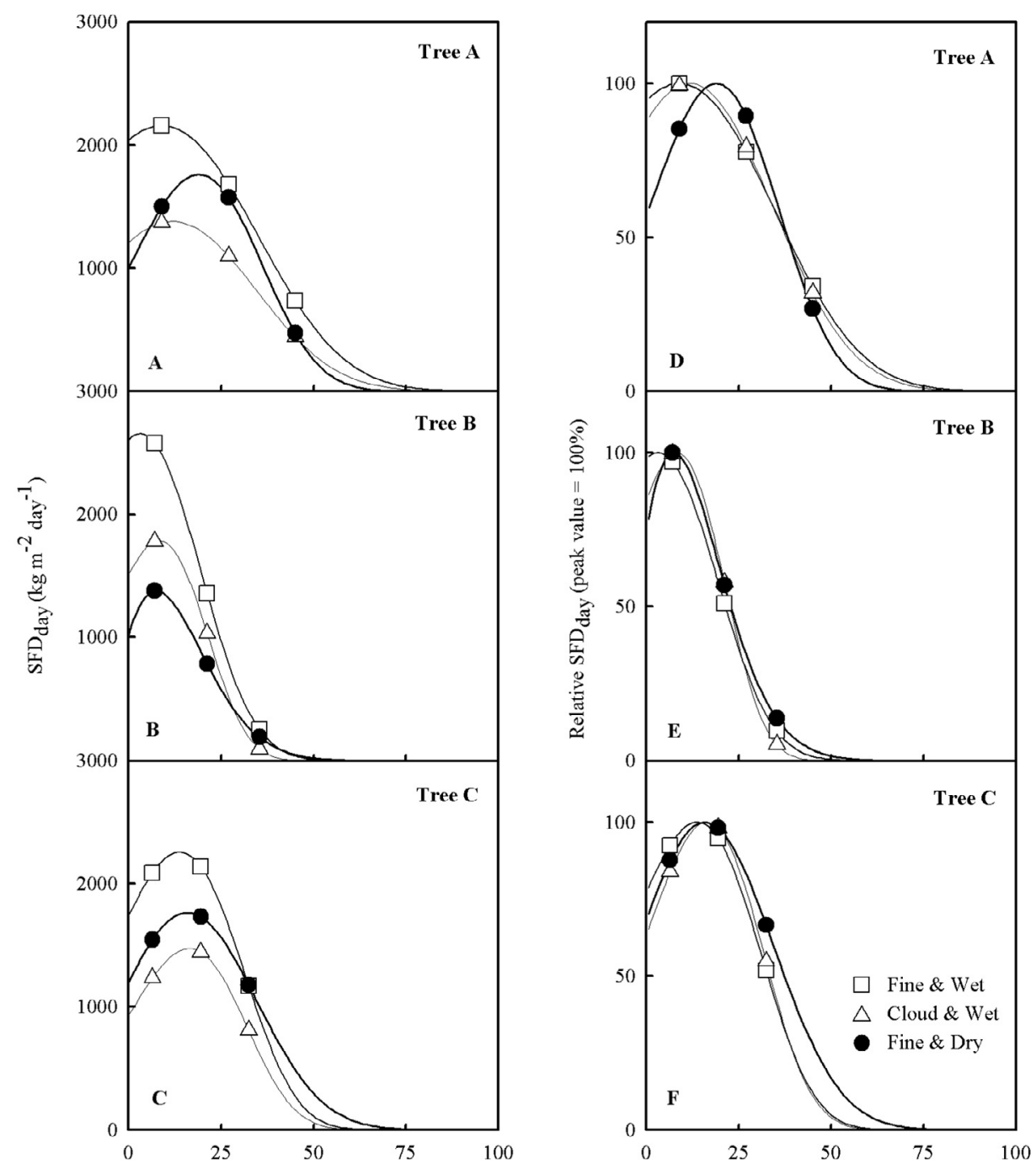

Figure 5. Radial patterns of $\mathrm{SFD}_{\mathrm{day}}$ using Weibull function under the three different sets of environmental conditions (the same environmental condition as Fig. 4) The radial pattern variation of SFD day (as shown in D-F) was converted to a relative value in which the peak value of $\mathrm{SFD}_{\text {day }}$ was assumed to be $100 \%$.

\subsection{Radial patterns of $\mathrm{SFD}_{\text {day }}$ using Weibull function with different environmental condition}

We continued our analysis of $\mathrm{SFD}_{\text {day }}$ patterns in the same trees by selecting very different environmental conditions as well as the preceding clause. Results are shown in Figure 5 for the fitted Weibull function obtained when: (i) Fine \& Wet, (ii) Cloud \& Wet, and, (iii) Fine \& Dry. As seen in the left panel of the figure, the peak value of $\mathrm{SFD}_{\text {day }}$ by Weibull function decreased with all trees by ca. $35 \%$ because of the decrease in the PPFD $_{\text {day }}$ (Fine \& Wet versus Cloud \& Wet). However, the decrease of the peak value of $\mathrm{SFD}_{\text {day }}$ under dry conditions (Fine $\&$ Dry) was different in each tree, e.g. that for trees $\mathrm{A}$ and $\mathrm{C}$ was ca. $20 \%$ that for tree B was ca. $50 \%$, indicating a large sensitivity to soil drying. The degree of response probably has to do with the rooting of individual trees and competition for water with neighboring trees and understory shrubs.
Finally, the radial patterns obtained with different environmental conditions were converted into relative values in which the peak value of the Weibull function was assumed to be $100 \%$ as shown in Figures 5D-5F. A shift in the Weibull relationship effectively describes changes in $\mathrm{SFD}_{\text {day }}$ with both differing PPFD input and water availability. In particular, the radial patterns differed when $\theta_{\text {day }}$ availability changed at high $P P F D_{\text {day }}$. The peak value of the Weibull function shifted inner 10\%, 4\% and $2 \%$ in the relative xylem depth in the Tree A, B and C, respectively. At least, the increase of $\mathrm{SFD}_{\text {day }}$ ratio of 20 $40 \mathrm{~mm}$ depth takes part in shifting the peak of the Weibull function. However, this point is not conclusive because there were no observations deeper than $60 \mathrm{~mm}$.

The $\mathrm{SFD}_{\text {day }}$ peak value may have moved toward the interior as observed for all trees when the soil water dries. Becker [1] and Nadezhdina et al. [20] reported that the decrease in sap flux caused by dry soil differed between the inside and outside of 
the xylem. On the other hand, Kubota et al. [18] did observe a differential recovery in flow in the inner and outer xylem after drought. Thus, further study with greater spatial resolution is needed. Nevertheless, even with drying, the shift in the fitted function was small, supporting the use of the Weibull function as a means for integration of what first appears as relatively heterogeneous data and, therefore, for scaling up of individual tree responses to stand level.

Acknowledgments: We thank Mr. Burkhard Stumpf, Dr. M. Naramoto, Mr. A. Iio and the members of the Institute of Silviculture, University of Shizuoka for field support, especially by sensor installations. This research was supported by the Ministries of Agriculture, Forestry and Fisheries of Japan, by a Grant-in-Aid for Scientific Research (No. B13460067) from the Special Coordination Funds of the Ministry of Education, Culture, Sports, Science and Technology of Japan, by the German Ministry for Education, Science, Research and Technology support to the Bayreuth Institute for Terrestrial Ecosystem Research (BMBF, PT BEO - 0339476 C), and by the University of Bayreuth Educational Association.

\section{REFERENCES}

[1] Becker P., Sap flow in Bornean heath and dipterocarp forest trees during wet and dry periods, Tree Physiol. 16 (1996) 295-299.

[2] Cermák J., Cienciala E., Kucera J., Lindroth A., Hallgren J.-E., Radial velocity profiles of water flow in stems of spruce and oak and response of spruce tree to severing, Tree Physiol. 10 (1992) 367-380.

[3] Ford C.R., McGuire M.A., Mitchell R.J., Teskey R.O., Assessing variation in the radial profile of sap flux density in Pinus species and its effect on daily water use, Tree Physiol. 24 (2004) 241-249.

[4] Granier A., Une nouvelle méthode pour la mesure de flux de sève brute dans le tronc des arbres, Ann. Sci. For. 42 (1985) 193-200.

[5] Granier A., Evaluation of transpiration in a Douglas fir stand by means of sap flow measurements, Tree Physiol. 3 (1987) 309-320.

[6] Granier A., Anfodillo T., Sabatti M., Cochard H., Tomasi M. Valentini R., Bréda N., Axial and radial water flow in the trunk of oak trees: a quantitative and qualitative analysis, Tree Physiol. 14 (1994) 1383-1396.

[7] Granier A., Loustau D., Measuring and modelling the transpiration of a maritime pine canopy from sap-flow data, Agric. For. Meteorol. 71 (1994) 61-81.

[8] Granier A., Biron P., Bréda N., Pontailler J.Y., Saugier B., Transpiration of trees and forest stands: short and long-term monitoring using sapflow methods, Glob. Change Biol. 2 (1996) 265-274.

[9] Granier A., Biron P., Lemoine D., Water balance, transpiration and canopy conductance in two beech stands, Agric. For. Meteorol. 100 (2000) 291-308.

[10] Granier A., Aubinet M., Epron D., Falge E., Umundsson J., Jensen N.O., Köstner B., Matteucci G., Pilegaard K., Schmidt M., Tenhunen J., Fluxes of carbon, water and energy of European forests, in: Ecological Studies, Vol. 163, Springer-Verlag, Berlin, Heidelberg, 2003, pp. 55-70.

[11] Habermehl A., Hüttermann A., Lovas G., Ridder H.-W., Computer Tomographie von Bäumen, Biologie in unserer Zeit 4 (1990) 193 200.

[12] Hunt M.A., Beadle C.L., Whole-tree transpiration and water-use partitioning between Eucalyptus nitens and Acacia dealbata weeds in a short-rotation plantation in northeastern Tasmania, Tree Physiol. 18 (1998) 557-563.

[13] Kakubari Y., Beech forests in the Naeba Mountains: Distribution of primary productivity along the altitudinal gradient, in: Shidei J., Kira T. (Eds.), Primary productivity of Japanese forest, JIBP Synthesis, Vol. 16, Univ. Tokyo Press, 1977, pp. 201-212.

[14] Kakubari Y., Primary productivity changes for a fifteen-year period in a natural beech (Fagus crenata) forest in the Naeba mountains, J. Jpn. For. Soc. 73 (1991) 370-374.
[15] Knights D.H., Fahey T.J., Running S.W., Harrison A.T., Wallace L.L., Transpiration from 100-yr-old lodge pole pine forests estimated with whole-tree porometers, Ecology 62 (1981) 717-726.

[16] Köstner B., Biron P., Siegwolf R., Granier A., Estimates of water vapor flux and canopy conduce of Scots pine at the tree level utilizing different xylem sap flow methods, Theor. Appl. Climatol. 53 (1996) 105-113.

[17] Köstner B., Granier A., Cermák J., Sap flow measurements in forest stands: methods and uncertainties, Ann. Sci. For. 55 (1998) 13-27.

[18] Kubota M., Tenhunen J., Zimmermann R., Schmidt M., Adiku S., Kakubari Y., Influences of environmental factors on the radial profile of sap flux density in Fagus crenata growing at different elevations in the Naeba Mountains, Japan, Tree Physiol. 25 (2005) 537-548.

[19] Lu P., Muller W.J., Chacko E.K., Spatial variations in xylem sap flux density in the trunk of orchard-grown, mature mango trees under changing soil water conditions, Tree Physiol. 20 (2000) 683692.

[20] Nadezhdina N., Cermák J., Ceulemans R., Radial patterns of sap flow in woody stems of dominant and understory species: scaling errors associated with positioning of sensors, Tree Physiol. 22 (2002) 907-918.

[21] Oliveras I., Llorens P., Medium-term sap flux monitoring in a Scots pine stand: analysis of the operability of the heat dissipation method for hydrological purposes, Tree Physiol. 21 (2001) 473-480.

[22] Oren R., Zimmermann R., Terborgh J., Transpiration in upper Amazonia floodplain and upland forests in response to drought breaking rains, Ecology 77 (1996) 968-973.

[23] Oren R., Phillips N., Katul G., Ewers B.E., Pataki D.E., Scaling xylem sap flux and soil water balance, and calculating variance: a method for partitioning water flux in forests, Ann. Sci. For. 55 (1998) 191-216.

[24] Oren R., Pataki D.E., Transpiration in response to variation in microclimate and soil moisture in southeastern deciduous forests, Oecologia 127 (2001) 549-559.

[25] Pataki D.E., Oren R., Smith W.K., Sap flux of co-occurring species in a western subalpine forest during seasonal soil drought, Ecology 81 (2000) 2557-2566.

[26] Phillips N., Oren R., Zimmermann R., Radial patterns of xylem sap flow in non-, diffuse- and ring-porous tree species, Plant Cell Environ. 19 (1996) 983-990.

[27] Phillips N., Oren R., A comparison of daily representations of canopy conductance based on two conditional time-averaging methods and the dependence of daily conductance on environmental factors, Ann. Sci. For. 55 (1998) 217-235.

[28] Phillips N., Bond B.J., McDowell N.G., Ryan M.G., Canopy and hydraulic conductance in young, mature and old Douglas-fir trees, Tree Physiol. 22 (2002) 205-211.

[29] Roberts J., The use of tree-cutting techniques in the study of the water relations of mature Pinus sylvestris L., J. Exp. Bot. 28 (1977) 751-767.

[30] Schafer V.R.K., Oren R., Tenhunen J., The effect of tree height on crown level stomatal conductance, Plant Cell Environ. 23 (2000) 365-375.

[31] Schulze E.-D., Cermák J., Matyssek R., Penka M., Zimmermann R., Vasicek F., Gries W., Kucera J., Canopy transpiration and water fluxes in the xylem of the trunk of Larix and Picea trees - a comparison of xylem flow, porometer and cuvette measurements, Oecologia 66 (1985) 475-483.

[32] Schulze E.-D., Flux Control in Biological System, Academic Press, New York, 1994, pp. 203-235.

[33] Tetens O., Uber einige meteorologische Begriffe, Z. Geophys. 6 (1930) 297-309.

[34] Whitehead D., Teskey R.O., Dynamic response of stomata to changing irradiance in loblolly pine (Pinus taeda L.), Tree Physiol. 15 (1995) 245-251.

[35] Zhang L., Dawes W.R., Hatton T.J., Modelling hydrologic processes using a biophysically based model - application of WAVES to FIFE and HAPEX-MOBILHY, J. Hydrol. 185 (1996) 147-169.

[36] Zimmermann R., Schulze E.-D., Wirth C., Schulze E.-E., McDonald K.C., Vygodskaya N.N., Ziegler W., Canopy transpiration in a chronosequence of Central Siberian pine forests, Glob. Change Biol. 6 (2000) 25-37. 